\title{
The Identification Of Merdeka Belajar (Freedom Of Learning) Values Through The Development Of Portfolio Assessment Instruments In Secondary Schools
}

\author{
Qurrota Ayu Neina ${ }^{1}$, U'um Qomariyah ${ }^{2}$ \\ neina@mail.unnes.ac.id ${ }^{1}$, uum@mail.unnes.ac.id ${ }^{2}$ \\ Department of Indonesian Language and Literature, Faculty of Language and Arts \\ Universitas Negeri Semarang ${ }^{1,2}$
}

\begin{abstract}
This study is aimed to describe the form of the identification of Merdeka Belajar (Freedom of Learning) values that can be applied in the portfolio assessment for middle and high schools. This study used the R and D research procedure from Borg and Gall. The research data consisted of (1) a description of the analysis result of freedom of learning values, (2) and the data analysis of the need for freedom of learning value-based portfolio assessment. The findings of this study are that there are three values that must be considered in finding meaning in the learning process, namely commitment, independence, and reflection. These three freedom of learning values are implemented in the learning. This wasembodied by integrating it in the portfolio assessment. Portfolio assessment was chosen because it is able to measure the success of the learning process comprehensively starting from the input, the process, to the output.
\end{abstract}

Keywords: freedom of learning, assessment, portfolio, $\mathrm{r}$ and $\mathrm{d}$ research

\section{Introduction}

Quality education reflects the constructive life of developed societies. This is in line with what [1] stated that education is expected to be able to lead students to achieve happiness in the real life and return to the true nature of humanity. Education is also a driving force so that culture can change according to changes obtained from the education itself. Therefore, education is the answer to achieving a better life.

In order to support this goal, the government issued a policy of "Merdeka Belajar" (Freedom of Learning). One of the policies for the this program is realized through the policy of eliminating the National Examination (UN). Nadiem in Berita Satu [3] revealed that the competencies contained in UN were too dense so that students tended to memorize only the material. In addition, this kind of examination tends to assess the cognitive aspects, and is more on mastery of the material, but has not touched the character aspect. Nadiem's opinion regarding his disagreement with the National Examination has also been summarized by [4], this opinion is based on three main 
reasons, namely 1) every student has their own potential, it cannot only be measured by a few subjects, 2 ) learning outcomes for three years will be unfair if it is only determined by the results of a-few-hour examination, and 3) not every school has the same human and facility resources, so it cannot be measured with the same measurement.

Following up on the program, the Minister of Education and Culture made a new direction of policy, which is to replace the National Examination with exams administered by schools. Exams to assess students can be done in written form and/or other forms of assessment that are more comprehensive. This is in accordance with the essence of the Law on National Education System (UU Sisdiknas) which provides flexibility for schools to determine graduation. With this program, it is expected that teachers will be more independent in assessing the learning outcomes of students.

However, many teachers have not been able to make assessment instruments based on the freedom of learningconcept. Instead of using a comprehensive assessment system, teachers are still trapped by the traditional assessment concept which only focus on the final result without paying attention to the learning process. Therefore, we need a guideline containing principles that can be used by teachers as a basis for carrying out freedom of learning-based assessments. One of which is by implementing a portfolio assessment.

Studies related to assessment, education, and freedom of learning have been conducted before, among others by [5], [6], [7], [8], [9], and [10].

[5] in his article entitled Teacher Portfolio Assessmentdiscussed the steps for implementing a portfolio assessment which consists of six stages, which are 1) starting slowly, 2) accepting all consequences, 3) investing ownership, 4) communicating the results of implementation, 5) referring to a model, and 6) selective. This article contributes in this study regarding the adaptation of the step implementation process in portfolio assessment.

[6] in their article, entitled A Portfolio Assessment Model for ESL, explained five characteristics in portfolio assessment that can be used as a systematic assessment tool in lesson plan and student evaluation. Each of these characteristics has implications for ESL classrooms. Those five characteristics are comprehensive, predetermined and systematic, informative, tailored, and authentic. The article contributes to this research regarding the adaptation of the characteristics contained in the portfolio assessment model.

The research conducted by [7] under the titleThe Implementation of Authentic Assessment in the Efforts to Improve the Quality of Educationconveyed the understanding and techniques for measuring the quality of education. From the existing techniques, it is considered that authentic assessment can be used by teachers and educational institutions in providing an overview of the quality of education obtained by students and the quality of education nationally. The article's contribution to this research concerns the concept of authentic assessment which forms the basis of portfolio assessment.

[8] in her article entitled Penilaian Portofolio dalam Lingkup Pembelajaran Berbasis Kompetensi (Portfolio Assessment in the Scope of Competency-Based Learning). Her article describes the implementation of a portfolio assessment model that is suitable for subjects that demand student learning output in terms of knowledge, skills and attitudes. The contribution of the article to this research is regarding the 
adaptation of the portfolio assessment components which include: 1) teacher notes, 2) student work results, and 3) student development profiles.

[9] in his article entitledPengembangan Instrumen Penilaian Portofolio Mata Pelajaran Bahasa Indonesia pada Kurikulum Tingkat Satuan Pendidikan SMP Kelas VII Semester Ganjil. This article describes the process, quality, andimplementation of the development of portfolio assessment instrumentof Bahasa Indonesia subjects in the first semester of the 7th-grade curriculum. The results of this study showthat the development process is in accordance with the Fienrich development model which includes the analysis stage, planning stage, design stage, development stage, and implementation stage. The article's contribution to this research concerns the process of developing a portfolio assessment instrument and using a quantitative approach to describe the quality and implementation of the portfolio assessment instrument.

[10] in his article entitledThe Application of Authentic Assessment As A Testing TechniqueIn Seafaring Vocational Education and Training. This paper contains the development of authentic assessment model as one of the assessment techniques adapted for competency testing in vocational school (cruise school). The results of this study indicate that precise and dynamic testing techniques have a significant effect on the accuracy of the test results to determine the level of competence. Simply, it can be said that authentic assessment can measure the level of competence a person has effectively. The article's contribution to this research concerns the adaptation of the concept of developing authentic assessment models in portfolios.

Based on the results of previous research and previous research studies, it is expected that this research can be followed up in research in the same field, namely creating educational innovation and development-oriented to learning evaluation products that have positive social impacts in society.

Freedom of learning is a new policy program of the Ministry of Education and Culture of the Republic of Indonesia (Kemendikbud RI) which was proclaimed by the Minister of Education and Culture of the Onward Indonesia Cabinet (IndonesiaMaju), Nadiem Anwar Makarim. [1] The essence of freedom of thought, according to Nadiem, must be preceded by teachers before they teach it to students. Nadiem said, in teacher competence at any level, without a translation process of the existing basic competencies and curricula, no learning will ever occur. The concept of freedom of learning in the style of Nadiem Makarim is motivated by his desire to create a happy learning atmosphere without being burdened with the achievement of a certain score or value.

The concept of a portfolio adopted into the education system becomes one of the assessment tools, especially for assessing (1) the learning process, (2) learning outcomes, or (3) the learning processes and outcomes of students [10][11]. It should only be noted that the assessment of learning with portfolios should not negate assessment in other ways, for example, by tests, actions, or others. However, not every collection of a student's work is called a portfolio. Portfolio "is only a collection of the work of a student as a result of the implementation of performance tasks, which are determined by the teacher or by the student with the teacher, as part of the effort to achieve learning goals, or achieve the competencies specified in the curriculum"[11].

From the background description above, the problem formulated in this research is how the form of identification of the values of independent learning can be applied in a portfolio assessment in secondary schools. The purpose of this research is to describe 
the form of identification of freedom of learning valueswhich can be applied in a portfolio assessment in secondary schools.

\section{Research Methodology}

This research used the $\mathrm{R}$ and $\mathrm{D}$ research procedure from [11]. For the needs of this research, it was adjusted to the objectives and actual research conditions. This research focused on the first and second steps, namely (a) research and information collecting and (b) planning. The variables in this research were the independent variable and the dependent variable. The independent variable in this research was the freedom of learning values. The dependent variable in this research was the principles of developing a portfolio assessment instrument.

In developing the principles of freedom of learning value-based portfolio assessment, two different data were needed, namely (1) freedom of learning values in the form of the analysis results description and (2) the analysis data of the needs for portfolio assessment in the form of the answer choice trend score. In developing the principles of developmental psychology-based children's stories, two instruments were needed, namely (1) an instrument to find out the data on the analysis result of the freedom of learning values in the form of an analysis table and (2) an instrument to determine the analysis of the needs for the freedom of learning value-based portfolio assessment in the form of needs questionnaire.

The research data consisted of (1) a description of the analysis results of the freedom of learning values and (2) the analysis data of the needs for freedom of learning valuebased portfolio assessment. In order to collect the first data, a literature review analysis table was used which was taken from various sources, such as books, research articles, and journals. To obtain the second data, a needs questionnaire was used aimed at secondary school teachers and students. In addition, to gain more complete data, unstructured interview techniques were also used. The data in this study were obtained using qualitative descriptive analysis, namely through data exposure and verification of data conclusions. This technique is used to determine the needs for the principles of developing freedom of learning value-based portfolio assessments.

\section{Findings and Discussion}

In order to discover the meaningfulness of a learning process, [13] revealed that we must pay attention to three values namely commitment, independence, and reflection. These values are still too broad and needed to be identified further so that it can be applied to the learning process. [2] formulated three basic components in freedom of learning program namely, 1)commitment, 2) independence, and 3) reflection. In this context, commitment is defined as a process of the students' involvement in determining the learning objectives. Whereas, the independence here is the process of assisting the students in finding the learning priority, learning method, and knowledge. As for the reflection is the process of guiding the learners to assess and determine the next step. Through this concept, freedom of learning is considered to be able to define the learning objectives clearly.

In supporting the concept, this approach is completed with an authentic assessment form, which is an assessment that emphasizes on the learning process. Portfolio 
assessment is one of them. Portfolio assessment is an assessment that is based on the performance, realisticness, and accordance with the learning. Moreover, this assessment contains information collected by various sources, undergoes a variety of methods, and through various points of time. By mastering the portfolio assessment principle based on the concept of freedom of learning, the teachers are expected to be capable of delivering meaningful learning and support the enhancement of the students' quality in life.

The values within the context of freedom of learning are basically defined from two terms namely, value and merdeka belajar (freedom of learning). The values of freedom of learninghold suchparticular definition as the foundation in comprehending the concept of the freedom of learning. In this context, value is defined as the essence attached to anything significant in human life ${ }^{[14]}$. In line with such idea, Kaswardi ${ }^{[15]}$ stated that value can be utilized as encouragement in life which gives meaning and legitimation of one's action. As for freedom of learning, it is concluded as a structuredlearning approach which is conditioned to fit the students need and help them in discovering the meaningfulness of learning process. In manifesting it, the learning process that is conducted must involve students' and teachers' roles synergistically. Thus, the values of freedom of learningcan be defined as the main things in supporting the learning in structure and culminating in the process of discovering the meaningfulness of learning. These values summarized in the table as follows.

Table 1. Freedom to learn and its implementation

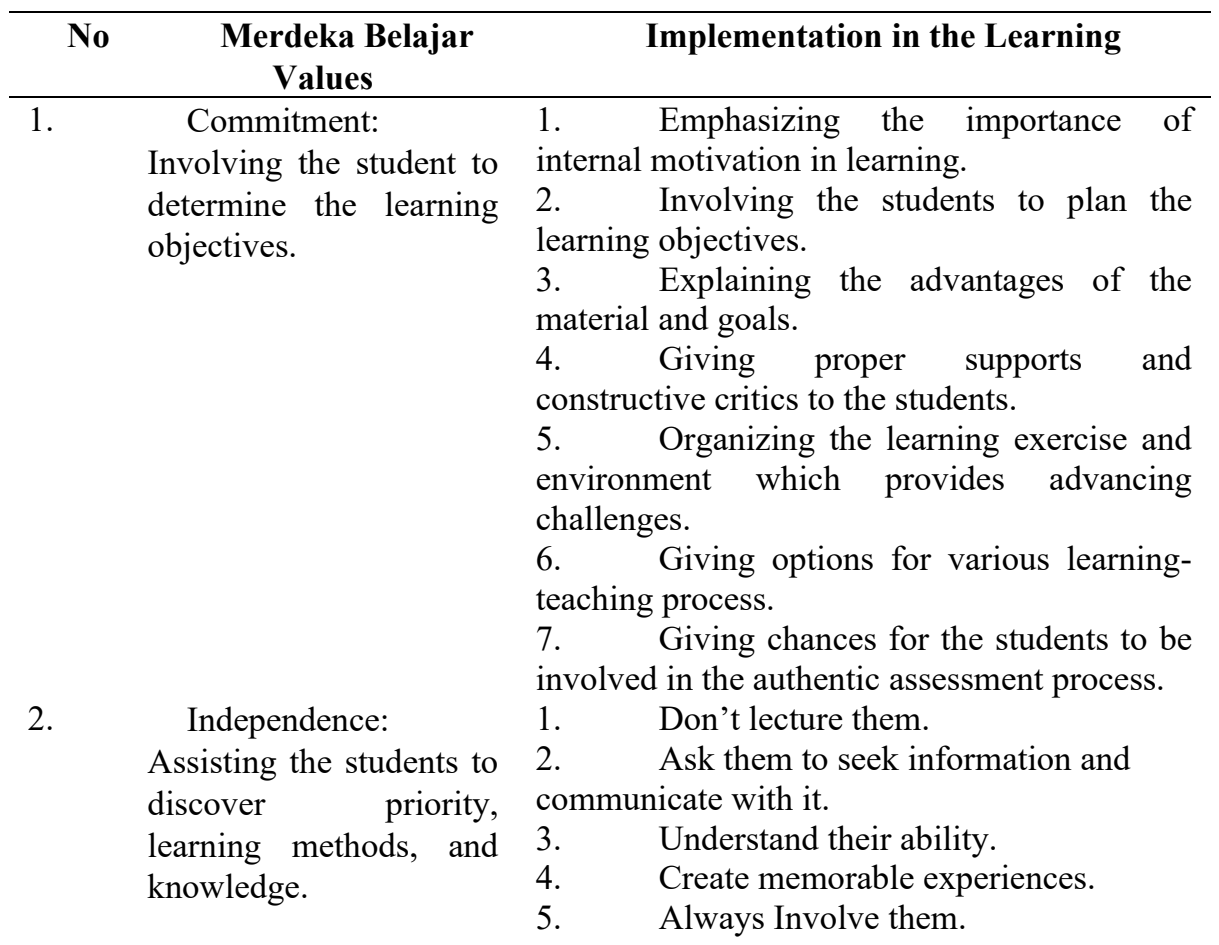


3.

Reflection: Guiding
the students to assess and
do the follow-up step.

6. Communicate that the failure in learning is acceptable.

7. Give a lot of feedback to them.

8. Believe that they have independence in learning from birth.

9. Develop positive routines and interactions.

1. Variating many forms of questions to generate their sense of creativity and sensitivity towards the material that is currently learned.

2. Documenting their learning process and results to help them evaluate their learning improvement.

3. Involving them in the assessment process of their works.

4. Providing specific time to reflect their learning.

The first freedom of learningvalue is commitment. Commitment existed in freedom of learningprogram is diligence applied through the acquisition goal that is meaningful for an individual. The ideal goal form of a learning process is to compete against oneself. If the learning goal is still referring to someone else or an external party, the thing that will be accomplished isonly the short-term goal. In order to grow sustainable commitment (long-term goal), it is required to understand the learning objectives and teachers' role in teaching. The teachers are expected not to use the external reward, such as grade or ranking as the goal.

Furthermore, the teachers must organize learning exercise and environment which provide advancing challenges in various situations inside dan outside of class, as well as train them to face the difficulties. In this context, teachers can cultivate the thoughts that failure is an inseparable part of the learning process. Teachers also can provide options in the various learning-teaching process: for example, selecting and leading an activity, choosing a group, and choosing the time. These options are based on the learning objectives. Furthermore, one which no less important is that teachers must also give students chances to be involved in theauthentic assessment process, including writing, assessing, and communicating the learning accomplishment in accordance with the learning objectives assigned.

The next thing to foster a sustainable commitment is the teacher's ability to focus on achieving goals, both daily and long-term. That can be implemented through students' involvement in planning the learning goals by explaining the relevance of learning to their daily lives. Besides, the teacher can also explain the benefit of the material or the goal which is originated from the teacher or the outside students and link it with the community's interests. This linkage does not have to be similar for every student because their interests and background knowledge are different. Furthermore, the most important thing is that the teacher can provide appropriate support and constructive criticism to the students showing that they are responsible for their learning process. 
They succeed because of their hard work, not because of the easy questions. They fail because of bad time management, not because of their piled tasks.

The second value of the freedom of learning is independence. Independence is one of the education's objectives. Fostering the students' independence requires a long process. In this context, the independence not only relies on the self-qualities such as perception and self-confidence but also on the environment. These two things are mutually complementary conditions.

In this case, the teacher's job is to design and ensure a supportive learning environment for the students' independence. That can be strengthened through the implementation of several values, which are 1) not lecturing students, this makes the students remember things in the short term only. 2) Asking the students to search for information and communicate their experiences. 3) Understanding the students' abilities by giving them learning challenges. Moreover, 4) creating experiences that will foster the students' self-confidence.

The next thing that can be done to foster the students' independence is the ability to motivate themselves when confronting difficulties. This can be strengthened through the implementation of several ways, which are 1) communicating that mistakes in learning are acceptable. 2) Giving lots of feedback tome students. 3) Believing that students have independence in learning from birth. In addition, 4) developing positive routines and interactions.

The third freedom of learning is reflection. In the context of freedom of learning, reflection is not only retrospect and introspection but also an analysis of the past experiences and future plans. This can be done by looking at the advantages and the disadvantages, then both conclusions can be used to determine the next plans. To conduct the continuous reflection process, the teacher can try by doing several ways, namely 1) varying different forms of questions to generate creativity and sensitivity of the students towards the material that is currently learned. 2) Documenting students learning processes and results to help them evaluate their learning progress. 3) Involving students in the assessment process of their work. Finally, 4) providing a specific time for a learning reflection.

These freedom of learning values were applied in the learning process. It was embodied by integrating it into the portfolio assessment. The assessment technique was chosen because it is able to measure the learning process comprehensively from input, process, to output. By implementing the values of freedom of learning, it is expected that students will no longer be burdened with the final results of a lesson that emphasizes a certain score or predicate. Students are expected to be able to find meaningfulness in the learning process. This can be done by exploring their abilities to realize that the long-term goal is superior compared to occasional predicates.

\section{Conclusion}

Three values that must be noticed to find the meaningfullness in the learning process are commitment, independence, and reflection. Commitment that exists in freedom of learning is diligence applied through the acquisition goal that is meaningful for an individual. Moreover, Independence in the freedom of learning is one of the education's objectives. Fostering students' independence requires a long process. Independence in this context does not only depend on the self-qualities, such as perception and self- 
confidence, but also on the environment. In the context of freedom of learning, reflection is not only retrospect and introspection but also an analysis of past experiences and future plans. These learning values were applied in learning process. This wasembodied by integrating it into portfolio assessment. The assessment techniquewas chosen because it is able to measure the learning process comprehensively from input, process, to output.

\section{References}

[1] Zein M. Peran Guru dalam Pengembangan Pembelajaran. J UIN- Alauddin [Internet]. 2016;V(2):274-85. Available from: http://journal.uinalauddin.ac.id/index.php/Inspiratif-Pendidikan/article/view/3480

[2] Halik A. Alasan Mendikbud Nadiem Hapus Ujian Nasional. Beritasatu.com [Internet]. 2019; Available from: https://www.beritasatu.com/nasional/590122-inialasan-mendikbud-nadiem-hapus-ujian- nasional-2021

[3] Triatmanto. Tantangan Implementasi Pendidikan Karakter di Sekolah. J Cakrawala Pendidik. 2010;1(1).

[4] Doolittle P. Teacher Portfolio Assessment. Pract Assessment, Res Eval. 1994;4(1):1994-5.

[5] Moya SS, O 'Malley JM. A Portfolio Assessment Model for ESL. J Educ Issues Lang Minor Students [Internet]. 1994;13(3):13-36. Available from: http://scholar.google.com/scholar?q=related:C8UXXssrBB0J:scholar.google.com/ $\&$ hl=en\&num=20\&as_sdt=0,5\%0Apapers3://publication/uuid/D3E6AC10-D1084F45-902A-138ED65D286D

[6] Muchtar H. Penerapan Penilaian Autentik dalam Upaya Peningkatan Mutu Pendidikan. J Pendidik Penabur. 2010;14(9):68.

[7] Setiamiharja R. Penilaian Portopolio Dalam Lingkup Pembelajaran Berbasis Kompetensi. EduHumaniora | J Pendidik Dasar Kampus Cibiru [Internet]. 2016 Aug 1;3(2). Available from: http://ejournal.upi.edu/index.php/eduhumaniora/article/view/2806

[8] Ichwan M. Pengembangan Instrumen Penilaian Portofolio Mata Pelajaran Bahasa Indonesia pada Kurikulum Tingkat Satuan Pendidikan SMP Kelas VII Semester Ganjil. J Univ Negeri Surabaya. 2012;1(1):216.

[9] Fauzi A. The Application of Authentic Assessment As A Testing Technique In 
Seafaring Vocational Education and Training. Int J Educ Res. 2020;8(3):1-8.

[10] Sumarna S, Hatta M. Penilaian Portofolio: Implementasi Kurikulum 2004. Bandung: Remaja Rosdakarya; 2006.

[11] Nasional DP. Pedoman Khusus Pengembangan Portofolio untuk Penilaian. Jakarta: Kurikulum 2004; 2004.

[12] Gall MD, Gall JP, Borg WR. Educational Research: An Introduction (4th ed.). New York: Pearson Education, Inc.; 1983.

[13] Shihab N. Merdeka Belajar di Ruang Kelas. Tangerang Selatan: Literati; 2017.

[14] Thoha MC. Kapita Selekta Pendidikan Islam. Yogyakarta: Pustaka Pelajar; 1996.

[15] Kaswardi EM. Pendidikan Nilai Memasuki tahun 2000. Jakarta: Gramedia Pustaka Utama; 1993. 